\title{
Culture and identity in the early medieval fenland landscape
}

\author{
Susan Oosthuizen \\ Reader in Medieval Archaeology \\ University of Cambridge Institute of Continuing Education \\ Madingley \\ Cambridge CB23 8AQ
}

Telephone: 01223746222

Email: $\quad$ smo23@cam.ac.uk

\begin{abstract}
The fen-basin is located in a region in which material culture had become largely Germanic by the mid-fifth century. This paper evaluates the contribution made to an understanding of that process of cultural change by place-names, archaeology and documentary records.

Archaeological evidence indicates little post-Roman abandonment of the fenland; the region continued to be inhabited and exploited. Patterns of intercommoning, the Tribal Hidage, and stray pieces of information recorded by Bede and Felix, demonstrate the presence of territorial groups across the whole basin by the mid-seventh century in a complex, almost certainly dynamic, hierarchy of subordinate and dominant polities, principalities and kingdoms, some with some Brittonic territorial names and others with names based on Old English elements. Most of the people who gave these place-names were like to have been descended from the Romano-British and prehistoric inhabitants of Britain. Different cultural traditions cannot be identified in their material culture, and many may have been bilingual. Such commonalities together with continuity across the region in structures governing rights of common pasture suggests that it is as likely that some sub-Roman polities evolved into sub-kingdoms as it is that other polities were created anew. There is nothing so out of the ordinary in such political changes that they might be ascribed to the influence of incomers. The influence of migration on the evolution of early medieval fenland culture remains enigmatic.
\end{abstract}

\section{Keywords}

Early medieval identity, landscape, governance, fen, common rights

\section{Introduction}

For more than a century interpretations of the early medieval fenland have been based on three premises: that migration from north-west Europe was responsible for the transformation in material culture in the fifth and sixth centuries, that the fen basin formed one of the principal routes into England for those immigrants, and that the fenland itself was almost completely deserted from the end of the Roman period into the seventh or eighth centuries, being entirely Anglo-Saxon thereafter. This paper takes a fresh look at the 
character of that early medieval cultural change in the fenland through the lens of social and political identity, using documentary, archaeological and place-name evidence.

The fen basin is a vast delta through which the rivers that drain eastern and midland England flow into the Wash. Its floor, barely sloping towards the sea, extends over 4,000 square kilometres and - before drainage from the seventeenth century onwards - was broadly divided between peat wetlands in the south, fed by rain and rivers, and silts in the north, separated from the sea by intertidal marshes (Figure 1). In the peatlands meres and lakes formed in pockets lying below sea level (Ordnance Datum, hereafter OD) and supported a wide variety of birds and fish. Seasonal flooding affected an intermediate zone between Ordnance Datum and an upper limit (the 'flood line') which rose in the post-Roman period to stabilise at around $3.5 \mathrm{~m}$ above OD by the eighth century (Hall 1987, p. 11). The higher ground of that intermediate zone tended to be dry in summer, supporting rich grazing on natural water meadows; reed, rush and sedge stood in lower areas where damp conditions persisted for most of the year. Areas sufficiently above the flood line to be permanently safe from inundation created 'islands' safe for permanent settlement. In the same period, episodes of marine flooding successively deposited large quantities of silt along the southern shoreline of the Wash, widening the barrier between the sea and the peat fen, pushing the coastline further north, and eventually also raising those silts sufficiently above the floods to support permanent habitation.

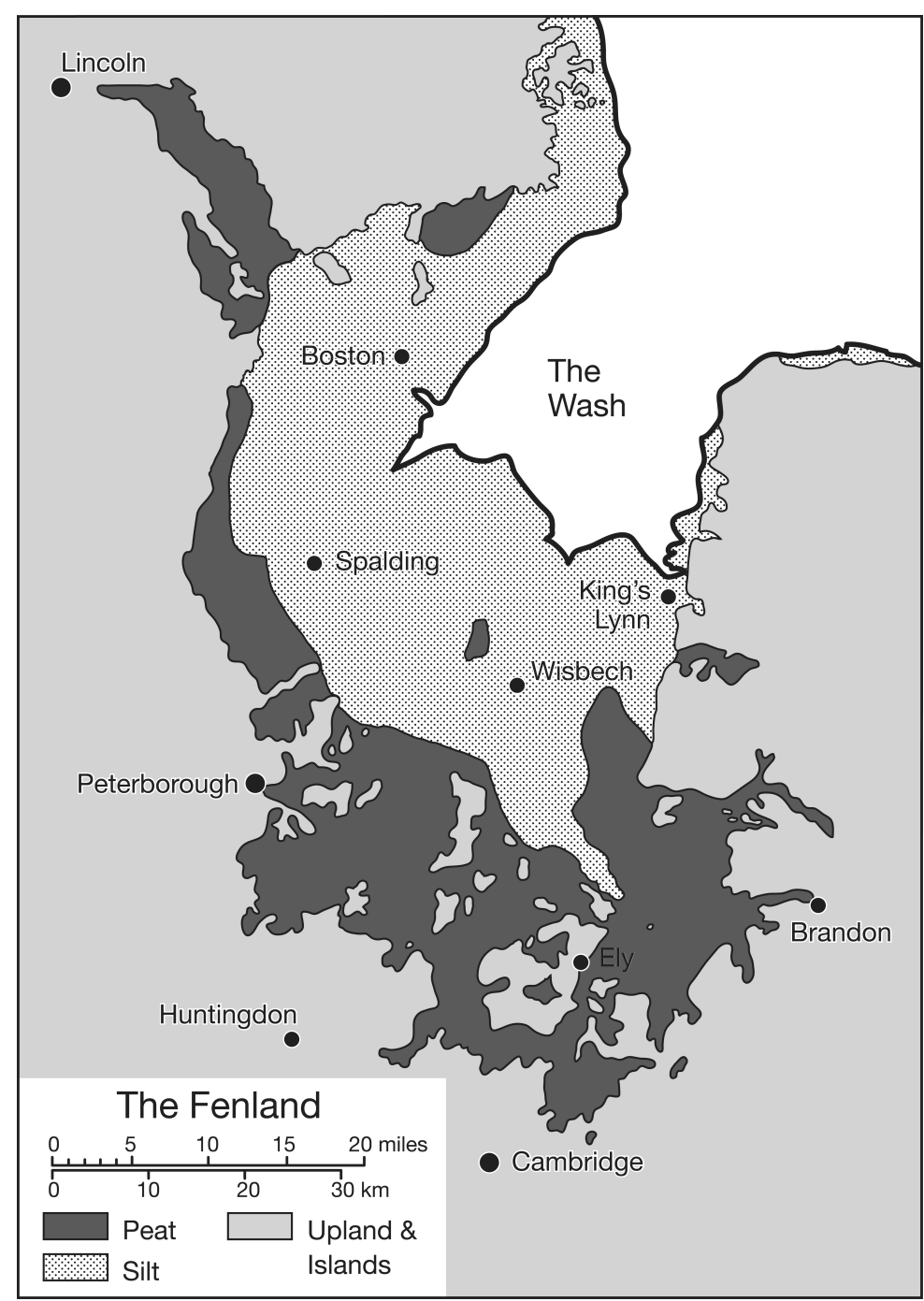

Figure 1. The geology of the fenland basin (based on Darby 1940) 


\section{A note on nomenclature}

Because the earliest documentary sources refer to the principal groups of migrants as Angles and Saxons, and because their subsequent influence on British culture was believed to have been so wide-ranging, it has become convention to refer to the period between about 400 and 1066 AD as 'Anglo-Saxon'. The meaning of the term is sometimes cultural, sometimes chronological, sometimes both.

The cultural identification of individuals or groups as 'Anglo-Saxon' is problematic for three reasons. The first problem lies in the recognition that cultural identity is constructed by both individuals and groups; neither material culture, birth nor language are necessarily indicators of identity (e.g. Hills 2011; Goffart 2006; Pohl 1997). The second reason is that, even if such ascription were possible, fifth- and sixth-century immigrants did not share a common background or even a common language: they came from different parts of northwest Europe with a wide range of cultural traditions (Pohl 1997, p. 25). The third problem is that the indigenous population of sub-Roman England is invisible within a period described as 'Anglo-Saxon'. Recognition of these complexities has led to the widespread acceptance of the term 'Germanic' in discussing north-west European influences on early medieval Britain; 'late British' has similarly been adopted to enable discussion of Romano-British influences (e.g. Geary 2002; Gillett 2006; Goffart 2006). Those distinctions are adopted below in relation only to material culture.

'Anglo-Saxon' is also commonly used as a chronological label. The period is conventionally subdivided into three: Early Anglo-Saxon, taken to lie between 400 and 650; Middle Anglo-Saxon between 650 and 850; and Late Anglo-Saxon between 850 and 1066 (cf. Hall \& Coles 1994: 122). That nomenclature is retained in this paper for ease of reference. It should not be read as having any cultural connotations.

\section{Historiography of the early medieval fenland}

For most of the twentieth century the historiography of fenland followed that of more general accounts based on early medieval histories. Gildas, for example, had described in about 540 how 'the Saxons' ... 'first of all fixed their dreadful claws on the east side of the island' in the mid-fifth century (Winterbottom 1978, p. 26). In 731 Bede had outlined how 'the Angles or Saxons came to Britain .. and were granted lands in the eastern part of the island' (Sherley-Price 1990, p. 62).

That early historiography was largely based on two premises. The first was that Germanic immigration was responsible for the transformation of early medieval material culture (e.g. Maitland 1897; Hoskins 1955, p. 45; Stenton 1971, p. 15; Fox 1923). In 1976, for example, David Wilson explained 'the clear distinction of material culture and political organisation between the Anglo-Saxons and the Romano-British population of England is the main reason with which one can draw a distinction between the two groups in the archaeological record. The Anglo-Saxons came from a Germanic stock..' (1976, p. 4). Since so much early Anglo-Saxon archaeology is focused on the east of England, it was assumed that many migrants entered the region through the fen delta (Darby 1934, pp. 193, 185; Fox 1923 , p. 276; Reaney 1943, p. xxx; Silvester 1988, p. 158). The first relatively modern review of Anglo-Saxon archaeology in Cambridgeshire was therefore unexceptional in its conclusion that the Cam valley had been settled by Anglian immigrants as early as 450 (Fox 1923, p. 276; see also Lethbridge 1931, p. 81). Modern surveys of the fens continue to suggest, explicitly or by implication, that early medieval fenland archaeology represents the activities 
of north-European colonists (e.g. Hayes \& Lane 1992, p. 213; Hall \& Coles 1994, p. 122; Penn 2005, p. 299).

The second premise was that the dominance of early Anglo-Saxon material culture across the basin could be explained in terms of repopulation by immigrants of a region abandoned in the early post-Roman period, the result of 'an increase in wetness that must have been devastating' (Hall \& Coles 1994, p. 122; see also Phillips 1970). That conclusion was supported by early histories recounting how Athelthryth's monastery at Ely in 673 lay in a landscape of 'prolonged desolation', just as Guthlac's hermitage was located in 'an uncultivated place of broad wilderness' (Fairweather 2005, p. 43; Swanton 1993, p. 93). The rapid abandonment of the fen basin explained the marked focus of early Anglo-Saxon archaeology on the fen-edge or the distant upland catchments of the rivers that passed through the basin, and the paucity of early place-names (Reaney 1943, p. xxviii; Arnold 1988, pp. 42-3, 54-5, 68, 165; Silvester 1985, p. 107; Hall \& Coles 1994, p. 128; Roberts \& Wrathmell 2002, pp. 34, 73-76; Williamson 2010, p. 152). Most communities were based on the fen-edge or, more sparsely, on the fen islands (Davies \& Vierck 1974, pp. 156, 283; Hall 1987, p. 11; Roffe 2005, p. 286; Rippon 2013, p. 335). Settlements on the north-western silt fens between Spalding and Wisbech continued to be occupied, possibly on a reduced scale, but those further east were thought to have been abandoned (Crowson et al. 2005, pp. 69, 102; Green 2012, p. 44; Silvester 1985, pp. 107, 156; Hall 1996, p. 82). Such conclusions underpinned Darby's colourful description of 'a frontier region ... the resort of brigands and bandits' (1940, p. 9).

The historiography of both the early medieval period in general and the fenland in particular have been radically re-assessed in the last decade. DNA analysis raises significant questions about the scale and character of early medieval population movements. While movement within the British Isles, and between Britain and Europe, has been continuous for millennia, most early medieval inhabitants of England were descended from a RomanoBritish population that could in turn trace its ancestry into the prehistoric period (Capelli et al. 2003; Weale et al. 2002; Leslie et al. 2015, pp. 310, 313 - 314). Widespread assimilation of small groups of early medieval north-European migrants into a large late British population are indicated by the homogeneity of modern English DNA and the absence of Germanic clusters in eastern or central England or 'Celtic' clusters in the west (Leslie et al. 2015, pp. 310, 313 - 314; Millett 1990, p. 185; Pattison 2008, p. 2425). Typological analysis of fifth- and sixth-century artifacts confirms those conclusions. Difficulties in identifying particular cultural traditions made it 'increasingly difficult .. to continue to think about the fifth and sixth centuries in eastern Britain as consisting of highly-distinctive ethnic communities' (Lucy \& Reynolds 2002, p. 10; see Brather 2005).

Archaeological and historical research begins instead to indicate the continued evolution of late British culture, albeit focused more on the North Sea in the early middle ages than it had been in the Roman period. Most people using Anglo-Saxon artefacts in the mid-fifth century were late British by birth and descent (Hamerow 1997, p. 33; see also Hughes et al. 2014). Apparently impeccable genealogies record the foundation of the AngloSaxon kingdoms by kings whose names were either British Celtic or included a British Celtic element: Cenwealh of Wessex (d. 672), Merewalh of the Magonsæte (d. late seventh century) and AEđelwealh of the south Saxons (d. c.685) (Gray 1911; Faull 1975, p. 35; Cameron 1978-9, p. 5; PASE). Artefacts like the royal regalia excavated at Sutton Hoo, once thought to be typically north-west European, express both Romano-British and Germanic traditions (Carver 1994, p. 2; Newman 2002, p. 505; Henig 2004; Laing 2007). And despite early descriptions of the apocalyptic annihilation of late Britons by north-west European migrants, British kingdoms survived into the early medieval period in central and eastern as well as in the west of Britain (e.g. Tyler 2007; Green 2012). British Celtic and Late Spoken 
Latin continued to be spoken into the early medieval period, and it is even possible that a Germanic dialect was already spoken in eastern England before the Roman Conquest (Tristram 2007; Schrijver 2014; Nash Briggs 2011). The conclusion that few inferences can be drawn about the cultural origins or background of individuals or communities on the basis of the artifacts they used or were buried with not only explains the apparent absence of late British populations in archaeological material, but also casts some doubt on the role of migration in stimulating changes in early medieval material culture.

Those conclusions might have fewer implications for the fenland if the basin had been deserted in the fifth and sixth centuries and later repopulated solely by immigrants from north-west Europe. Yet that premise is also now in doubt. The fen islands and the silt fens show a degree of occupation unexpected a few decades ago (Figure 2). Dense RomanoBritish settlement appears to have been followed by consistent early medieval occupation, despite the impact of climatic change (Phillips 1970; Hall 1987). There was 'extensive' early Anglo-Saxon occupation of the north-western silt fens between Spalding and Wisbech, and settlement of the same period has also now been recognised in the eastern silt fens (Penn 2005, p. 299; see also Hayes \& Lane 1992, p. 69; Silvester 1985, pp. 107, 156; Hall \& Coles 1994, p. 126; Crowson et al. 2005, pp. 69, 102, 290-292; Green 2012, p. 44). Early AngloSaxon cemeteries and other finds have been discovered on every island in the peat fens (e.g. Fox 1923, p. 263; Hall 1987, pp. 46, 59, 66; Hall \& Coles 1994, pp. 122-131; Hall 1996, p. 82; Cambridgeshire HER). In many cases, such sites represented the uninterrupted occupation of Romano-British sites (Taylor 1973, p. 63; Hall \& Coles 1994, p. 130). Neither abandoned nor desolate, fenland appears to have been continuously occupied throughout the early medieval period (CHER; Ouse Washes, Section 1: 56).

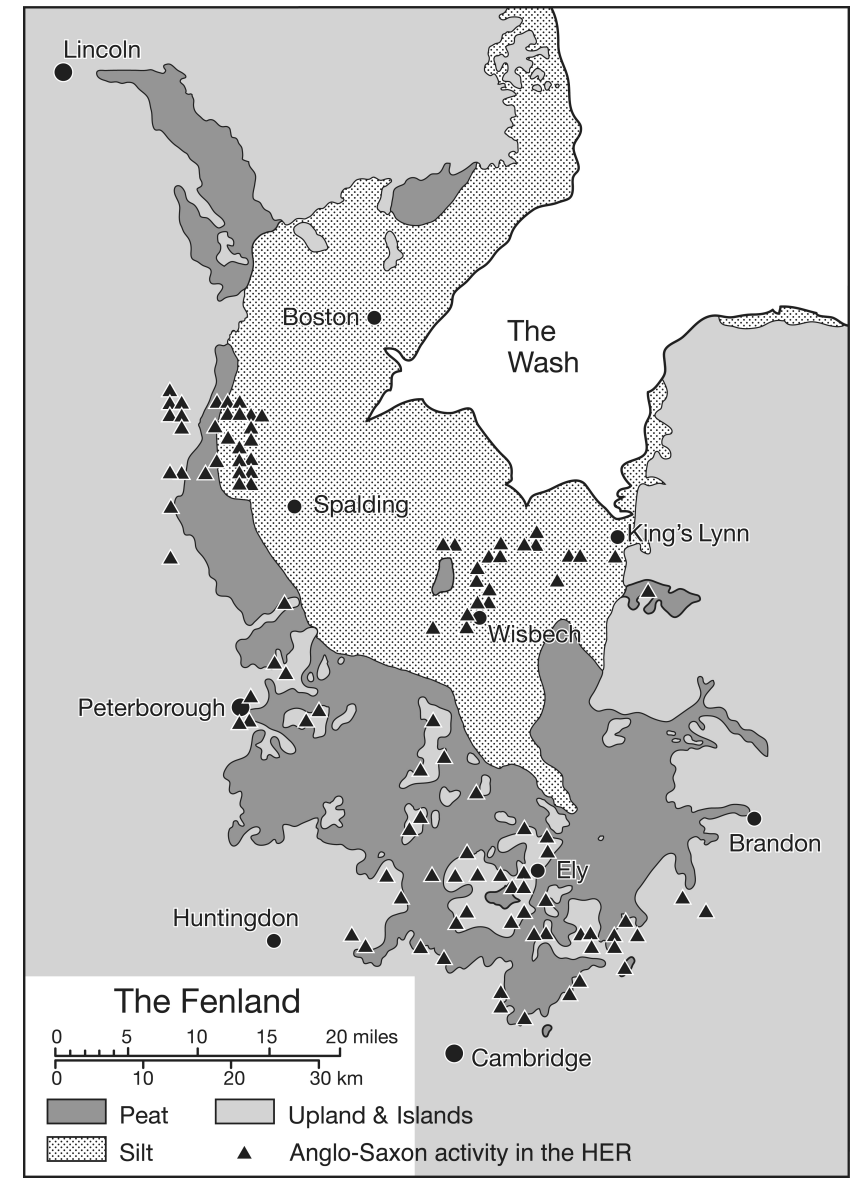

Figure 2. Early and middle AngloSaxon archaeology in fenland (data from Cambridgeshire HER) 
The uniformity in material culture across the fen basin also challenges accepted explanations, archaeologists noting 'the contrast between the historical evidence for independent groups in the fens and the lack of archaeological distinction between sites; i.e. a shared material culture' (Penn 2005: 289; see also Hayes \& Lane 1993, p. 68). In the past, early medieval cultural uniformity could be explained as the introduction by migrants into a deserted landscape of new forms of material culture. Now not only was it impossible to distinguish between migrants coming from different parts of north-west Europe, but distinctions between 'migrant' and 'indigenous' populations were as elusive. Continuous occupation of the fen basin across the fifth and sixth centuries forced the recognition that cultural change does not necessarily reflect demographic displacement (Penn 2005, p. 291).

\section{Political organisation in the later seventh century fens}

Persistent settlement does not, however, necessarily imply continuity in formal structures of governance. What were the political conditions within which early medieval fen communities lived? Was the region an anarchic wilderness inhabited by brigands and bandits, or is there evidence of political organisation and stability?

The Tribal Hidage is the earliest post-Roman document to describe the political geography of central and southern England in any detail. It is an opaque record, perhaps of the late seventh century, of smaller and larger kingdoms and/or territories paying tribute to the kingdom of Mercia. The list includes a number of minor political units, each assessed at between 300 and 600 hides, believed to have been located along the borders of the fen basin (Hart 1971; Davies \& Vierck 1974). They include: the spalde (assessed at 600 hides), the north and south gyrwe (each assessed at 600 hides), the east and west wixan (assessed at 600 and 300 hides respectively) and the east and west wille (also assessed at 600 hides each) (Hart 1971, pp. 134, 137; Figure 3). There is reasonable consensus about the identification of the regions occupied by the first two: the territory of the spalde is almost certainly coterminous with the medieval wapentake of Elloe on the south Lincolnshire silt fens, in the vicinity of Spalding, while the province of the gyrwe has definitively been located along the western fen-edge in Northamptonshire, to the north and south of Peterborough (Hart 1971, pp. 142-3; Davies \& Vierck 1974, pp. 273, 281-4; Roffe 1993; 2005, pp. 286, 2932; Green 2012, pp. 170-185). There has been more debate about the location of the wixan and the wille. Hart proposed that the territory of the wixan should be identified with that of the provincia Wissa, not mentioned in the Tribal Hidage, but listed in the eighth-century Life of Guthlac which explained that Æthelbald - later king of Mercia - had been in exile in among the wisse before 715 (Hart 1971, p. 144; Swanton 1993, p. 112). Hart followed Ekwall in suggesting that the wixan/wisse occupied a region between Wisbech and the river Wissey that included the Isle of Ely; and he placed the west and east wille in upland Cambridgeshire south of the fens (Ekwall 1928, pp. 465-7; Hart 1971, pp. 144, 153). Three years later Davies and Vierck suggested that the wixan were located beyond East Anglia and proposed instead that the isolated 'tribal area' of the east and west wille might be identified with the Isle of Ely (1974, pp. 273, 281-4). A recent review by Roffe has returned to and extended Hart's position, locating the wisse on the eastern silt fens and suggesting that they constituted a sub-kingdom of the wixan; he agreed with Davies and Vierck that the wille probably dominated the peat fens in the south (2005, pp. 284-5). Penn, too, concurred that the wisse should be located between Wisbech and the west Norfolk fen edge (2005, p. 298).

There is, then, general agreement among scholars on the geography of minor kingdoms and principalities in the north and west of the early medieval fenland. Divergences between them are only to some extent based on etymological arguments which correlate names in the Tribal Hidage with modern place-names. Their differences in relation to the 
political geography of the wixan/wisse/wille in the eastern and central fenland result from a methodological fallacy that is largely unacknowledged. As Roffe has succinctly observed, 'on its own the Tribal Hidage is just a series of names ... Pushing the names around on a map is of little help' (2005, pp. 3-4). Analyses of the Tribal Hidage were based on the premise that it offered a fairly complete overview of early medieval political organisation in the fenland without blank spaces. The problem was that, at least as regards fenland, there was a blank space: Ely was not listed in the Tribal Hidage.

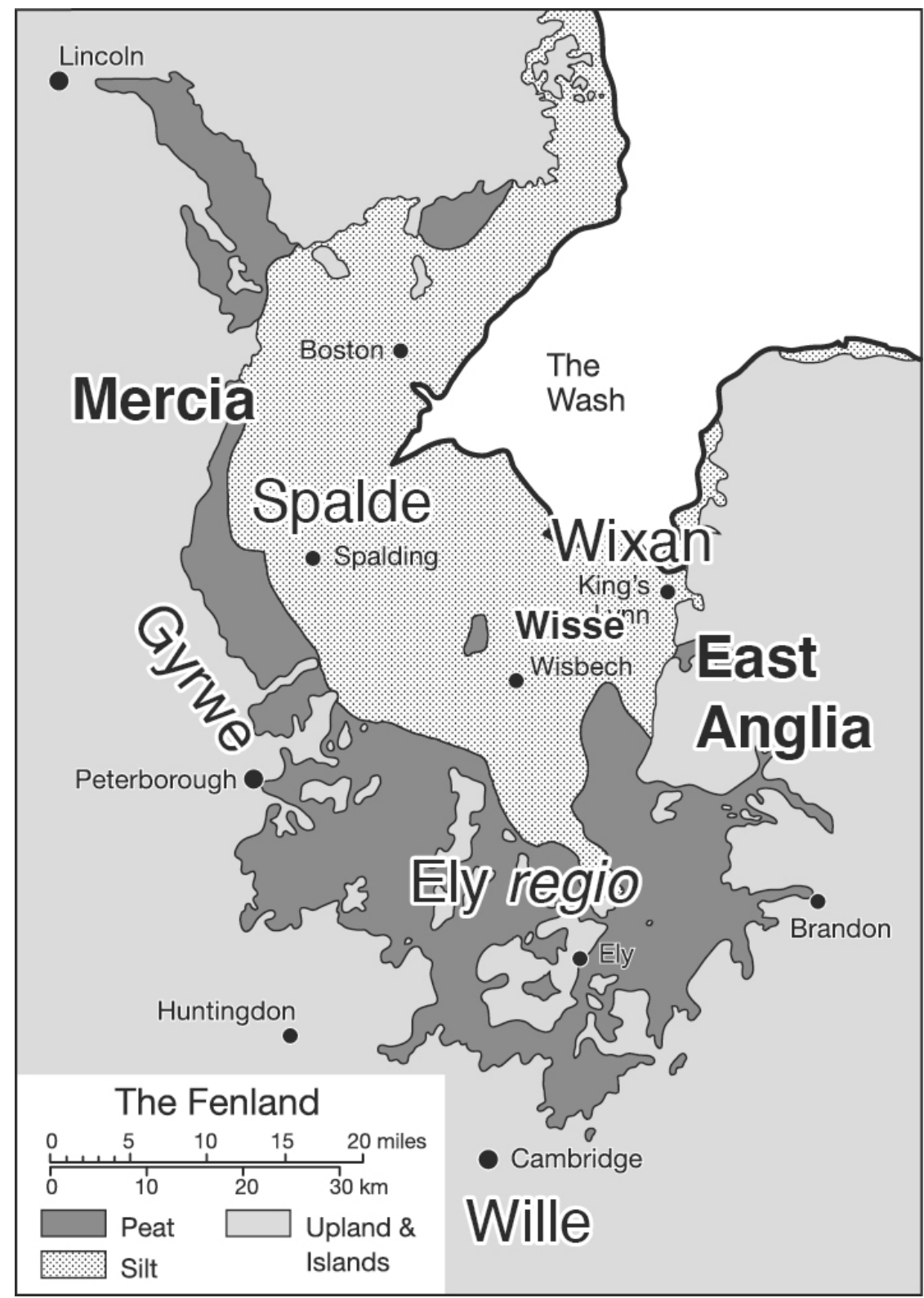

Figure 3. Suggested political geography of fenland in the later seventh century

The problem of Ely is based on Bede's explanation in 731, just a generation or so after the Tribal Hidage was compiled, that $/ E$ thelthryth had founded her monastic house in 673 in the regio (small sub-kingdom) of Ely. The (later) Old English translation of what he wrote made the meaning even plainer: 'in thæm theodlonde the is gecéged Elige' - which might be glossed as 'among the nation who call their territory Ely' (Skeat 1901, p. 52; cf. Smith 1956, ii, p. 203). Bede also noted that the regio was assessed at 600 hides, a political entity at least as substantial as others in the region that were included in the Tribal Hidage. 
There are at least four possible explanations for the omission of Ely from the Tribal Hidage. First, the regio should have been included in the list but was simply left out for unknown reasons, and reconstructions of the seventh-century political geography of fenland should show it as a blank space. Second, the regio may have emerged in the half century or so between the compilation of the Tribal Hidage and 731; that is, that Bede assumed that conditions in 673 were the same as in 731, when they were not. A third explanation might be that Ely was mentioned in the Tribal Hidage, but under a different name. Or, fourthly, that Ely was invisible in the Tribal Hidage because it was included within the assessment of another kingdom to which it was subordinate.

Generally speaking, scholars have implicitly recognised the problem, adopting the third proposition to explain it. The twelfth-century Liber Eliensis placed the early medieval province of Ely within the kingdom of the southern gyrwe since it said that Æthelthryth had received the estate from her first husband Tonbert, a prince of that kingdom (Fairweather 2005, p. 17). Hart's location of the gyrwe along the western fen-edge, on the basis of charter evidence, ruled this explanation out and thus left the problem of Ely unresolved (1971). Recognising that the territory of the east wixan was assessed at 600 hides in the Tribal Hidage, he argued that, because Bede had noted the regio of Ely was also assessed at 600 hides, the two names were the same (Hart 1971, p. 144; Sherley-Price 1990, p. 239). Davies and Vierck thought that Bede had made a mistake and suggested instead that Ely lay in the territory of the west wille since the most easterly course of the Ouse was also called the Well Stream (1974, pp. 231, 234, 256).

A careful reading of Bede, however, indicates that the fourth position might be more accurate. He was, after all, writing just 60 years after $\mathbb{E}$ thelthryth's death and appears to have been in contact with people who knew her, while the Liber Eliensis was compiled five centuries later. Bede judiciously explained that Ely was granted to \&Ethelthryth because the regio 'lies in the province of the East Angles' and because 'her forbears came from the province of the East Angles' (Sherley-Price 1990, p. 239). That is, Bede took it for granted that Æthelthryth's house was established within an existing political territory whose origins and East Anglian fealty long predated its foundation. Some support for the presence of an early polity based on the peat fens may be found in the place-name of Little Thetford (thēod, 'nation' and 'ford') where an ancient route crossed the river Granta (now the Cam, see below), the south-eastern boundary of the Isle. It passed through Soham, perhaps the site of the early seventh century royal East Anglian minster established by St Felix, and led to the villa regia at Exning where $\mathbb{E}$ thelthryth was born (Fairweather 2005, p. 20; Reaney 1943, p. 242; Webster 1987; VCH 10, p. 533). The gift to Kthelthryth of an established polity with close links to East Anglia mirrored her own origins in the heart of the East Anglian royal family (cf. Warner 1988, pp. 17-21).

The etymology of Ely's place-name, first recorded by Bede in 731, supports arguments for its early origins. The name is made up of two elements: $æ l$ or $\bar{e} l+g \bar{e}$ ( Reaney 1943, p. xxx). The second element, $g \bar{e}$, may represent an archaic Old English element meaning a territory, district or province, perhaps from the same root as modern German gau. Reaney suggested that it was 'a name of high antiquity' which had become obsolete very early in the early medieval period (Reaney 1943, p. xxx; see also Smith 1956, i, p. 196; Skeat 1901, p. 52). The origin of the first element, æl or el, is uncertain - even Bede does not seem to have been quite sure what it meant: because it sounded like 'eel' he simply glossed it as named from the many eels in fenland, but whether or not that really was the case is unknown (Reaney 1943, p. 214; but see Skeat 1901, p. 52). More recently, Briggs has suggested that the name was newly-coined in the seventh century (forthcoming, p. 19). The apparently archaic character of Ely's place-name which referred both to its caput and its territory, an early eighth-century record of that name, and Bede's confidence that it referred 
to an existing theodlond, all suggest that by the mid seventh-century the largest part of the peat fens already lay within a polity of some antiquity.

Neilson argued that the territorial extent of such early political units in the fenland might be preserved in medieval rights of common and intercommon (Neilson 1920, pp. vIviii; Figure 4). Her arguments were based on a number of observations: that rights to specific fenland intercommons were governed not by manors but by right-holders drawn from exclusive groups of vills; that all commoners had equal rights in the governance and exploitation of such commons, whether they were tenants or manorial lords; that rights of common were legally enforceable; and that the courts in which commoners collectively participated had powers of governance, justice and taxation and took precedence over manorial courts. On this basis, she suggested, the powers of such courts over large areas of natural resource were relics of the governance structures of early polities formed long before the emergence of the major kingdoms. Her point was illustrated in a map showing clustered distributions of intercommoning vills in the medieval fenland each focused on a discrete area of the fen that might correlate to identifications of territories listed in the Tribal Hidage. For example, common rights in Great Postland and South Holland fens were exercised by the vills on the silt fens of Holland, now the Wapentake of Elloe - an early 'folk' territory already identified with the spalde; or the coincidence between the entitlement of all vills in the soke of Peterborough to common in Borough Fen with the territory of the gyrwe (Neilson 1920, pp. xxxiv-vi, xliv, xlvii; Douglas 1927, p. 196; Hart 1971; Figure 4). If Neilson's conclusions were sound, the persistence of common rights suggests a considerable degree of political stability from at least the early Anglo-Saxon period into the middle ages and after.

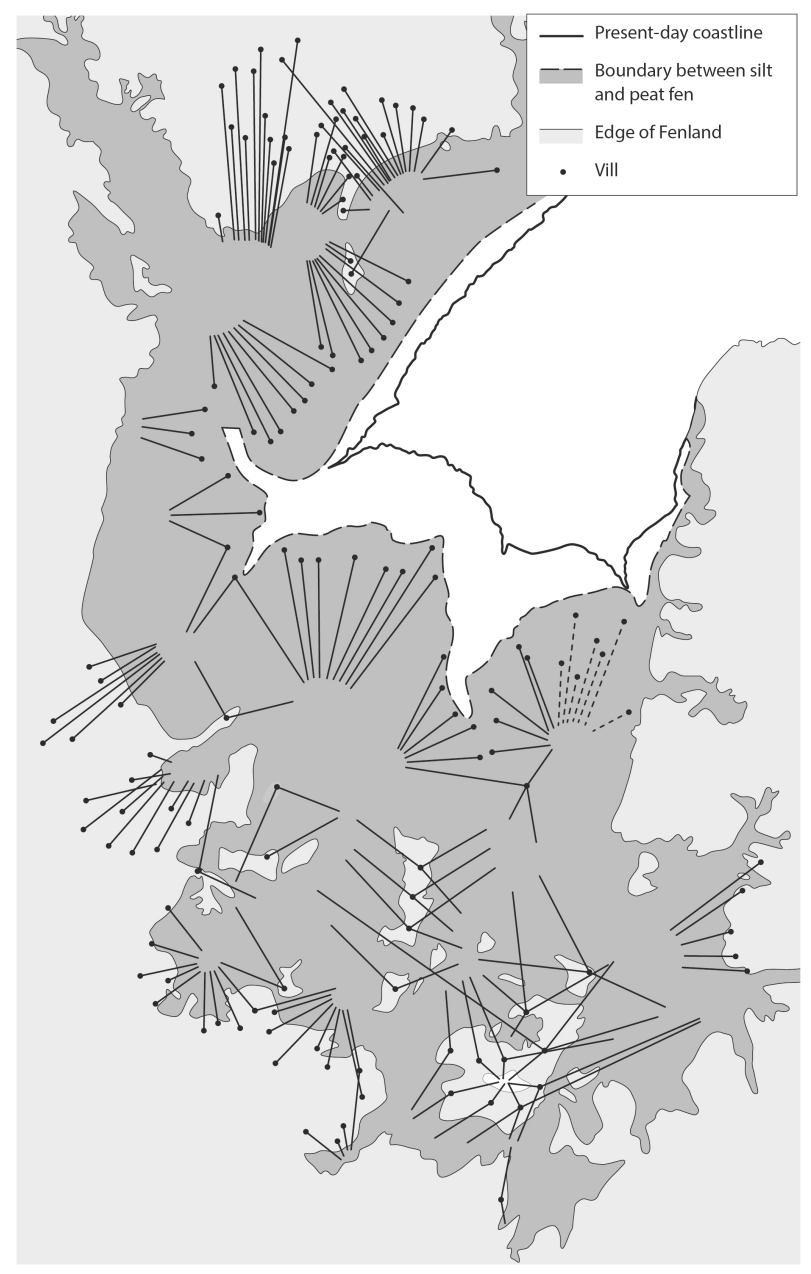

Figure 4. Medieval common rights in fenland (based on Neilson 1920, with additions from ECB) 
How might the history of rights of common illuminate the territorial limits of the early Anglo-Saxon regio of Ely? That question is unpromising at first glance since Neilson identified relatively few common rights in the peat fens - a significant contrast with the clearly-defined rights of fen-edge and siltland territories (1920). The mid-thirteenth century Ely Coucher Book, however, common rights in the peat fens of every vill in the four hundreds of Ely: those on the eastern slopes of the Isle commoned almost to the Suffolk fenedge; those on the western slopes commoned across the extensive pastures to the south and west; vills on the archipelago from Chatteris to March commoned both to east and west, being entitled to range as far as the western, Northamptonshire, fen-edge (BL Cotton Claud. C.xi, f.25v(1); CUL EDR, G3.27 f.25r(2)). Perhaps most significantly, rights of common in Ely itself - the eponymous caput of the seventh-century regio - provided an entitlement to graze stock across virtually the entire peat fen (Figure 4). If Neilson's arguments for other parts of the fenland hold, then the likelihood that these rights of common preserve the original extent of the territory of the regio of Ely might also be admitted.

In summary then, recent archaeological finds demonstrate that there was early medieval occupation across all or most of the fen basin. The Tribal Hidage and Bede's History, together with records of medieval rights of intercommon over vast areas of fen pasture, indicate the existence by the end of the seventh century of smaller and larger clanor kin-based territories that may have originated in 'the early days of [the Anglo-Saxon] settlement' (Neilson 1920, p. xlix, my addition). The argument turns now to the cultural identity of those political units.

\section{The communities of the early medieval fenland}

Who were mid-seventh century communities that lived in and managed these landscapes? There is sparse evidence from which to investigate this question: some place-names, a limited number of documentary sources and a handful of early charters (frequently of dubious provenance).

\section{Old English place-names}

There are, perhaps, around thirteen early place-names of Old English origin in fenland, of which ten can securely be identified. That small number is especially remarkable given the fact that the transition from Romano-British to Germanic material culture had been completed in eastern England by the mid-fifth century (e.g. Fox 1923, p. 27). That discrepancy between archaeology and place-names in the region was acknowledged as a problem almost from the outset. Stenton admitted in 1940 that 'the local names of the Fens are very difficult', since their small numbers were at odds with his conclusion that they proved that 'this whole country had been explored, and was being exploited, and had been named far back in the Anglo-Saxon period' (cited in Darby 1940, p. 8). Just a few years later Reaney, too, noted the relative rarity of early 'Anglo-Saxon' place-names (1943, p. xxx).

Nevertheless, at least three of those names are particularly ancient. All were formed from archaic elements and appear to have had territorial connotations: Ely (discussed above), Mepal and March (Figure 5). Mepal (Meahala 12thC, 'tribal name') has enigmatic origins (Reaney 1943, pp. 235-7; ECB); March (Merch 995 x 1002, mearc 'a boundary') is conventionally explained as referring to a hypothetical north-south boundary dividing the fens roughly equally between Mercia and East Anglia (Reaney 1943, p. 253; Darby 1934). The place-name is, however, the only evidence for that boundary, and the name may instead refer to March's location on the 'well-defined boundary of exploitation' between peat and silt fens which ran roughly from west to east and which was also territorial (Roffe 2005, p. 283; Figure 4). Reaney suggested Elm (AEIm c.1121, ASC E; Eolum, 13thC sources) may have 
been 'the name of one of the Germanic peoples visited by Widsith', but 'elm trees' is as likely an interpretation (Reaney 1943, pp. 266-7; KEPN).

The remaining early Old English place-names in the peat fens preserve the otherwise forgotten identities of minor clans or kin-based 'folk' almost all of whom can now only be identified through their use of the -ingas, 'small clan', suffix: the Bilsingge (13thC) at Beezling Fen in Doddington, and the Beorningas (Berengal(e) 1285) at Brangehill Drove in Sutton (Reaney 1943, pp. 252, 239-40). It is just possible that Grunty Fen (Gruntifen 1221, gruntho, n.k., -ing) a large area of intercommoned fen in the Isle of Ely, might record another (Reaney 1943, p. 231). There are a further six place-names on the silt fens that include one or more Old English elements, of which five may include-ingas: Spalding ('spald 'ditch', -ingas 'small clan'), Islington (elesa personal name, -ingas 'small clan', tūn 'small estate'), Terrington (tir(a) personal name, -ingas 'small clan', tūn 'small estate'), Leverington (Leofhere personal name, -ingtūn 'small estate') and Quadring (hæfer n.k., ingas 'small clan') (Reaney 1943, p. 271; Roffe 2005, p. 282; KEPN). Of these, Spalding and Islington are regarded as most secure and Leverington the least (KEPN). Clenchwarton (clenc 'hill', wara 'public land', tūn 'small estate') is a small parish of reclaimed salt marsh on the northern-eastern periphery of the eastern silt fens.

In conclusion, then, the character and distribution of Old English place-names in fenland confirms that it was spoken across fenland from an early date. On the other hand, that evidence is sparse compared with the rapid and extensive adoption of Germanic material culture. Taylor took a more empirical approach than other researchers in dealing with the problem. He concluded that the dearth of linguistic evidence simply suggested a cultural rather than a demographic shift, a suggestion explored in more detail below (1973, p. 50).

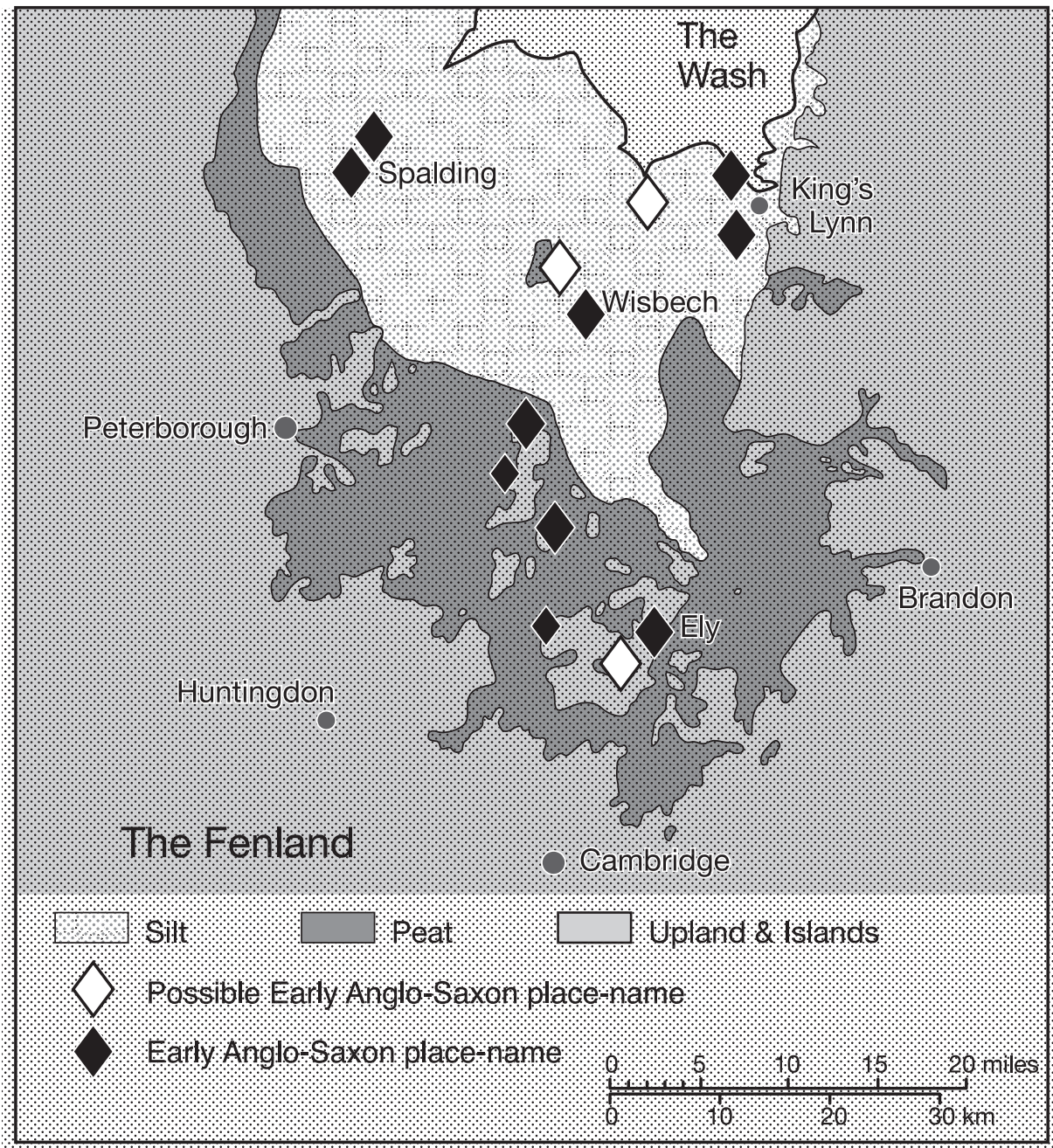

Figure 5.

Early AngloSaxon placenames in fenland 


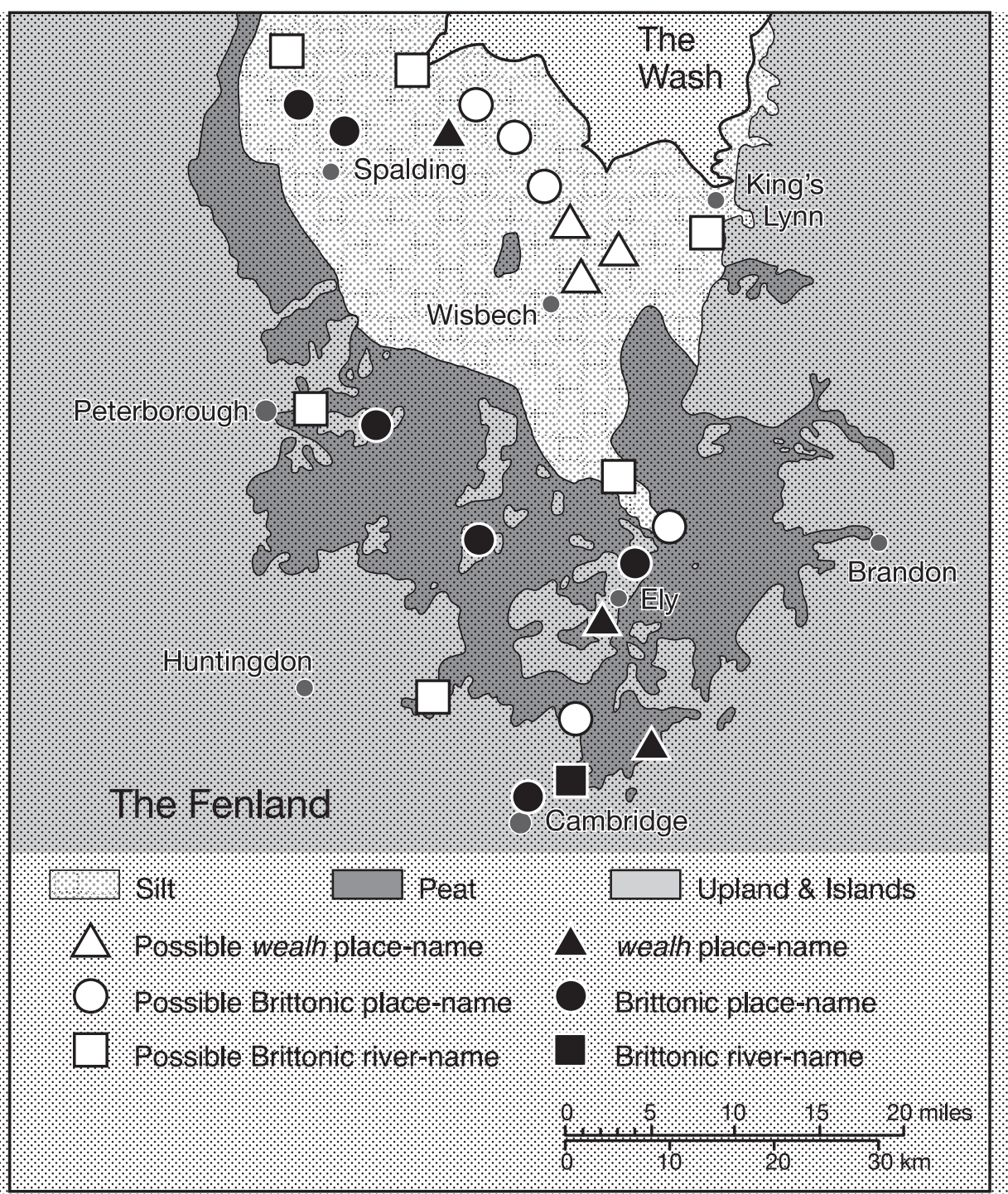

Figure 6.

Brittonic placenames in fenland, and place-names referring to Britons

\section{Brittonic and Late Spoken Latin speakers in the early medieval fenland}

Little is known about the languages of sub-Roman Britain, although they are assumed to have included Brittonic (British Celtic) and Late Spoken Latin; both are believed to have been spoken well into the early medieval period (e.g. Tristram 2007; Schrijver 2014, pp. 33-34, 48). More controversial is the suggestion that 'a non-Latin, non-Brittonic, but possibly West Germanic language' may already have been in use in eastern Britain during the late Iron Age, five or more centuries before the Adventus (Nash Briggs 2011, p. 99). The possibility is suggested that the early medieval population may have been bilingual, perhaps even multilingual.

The mid eighth-century Life of St Guthlac provides the earliest documentary evidence for Brittonic speakers in fenland (Swanton 1993, p. 93). There are four reasons for thinking this account is reasonably reliable. The Life was written between 730 and 740, less than a generation after Guthlac's death in 714; and Felix, its author, was East Anglian and thus familiar with the region. The third reason is that some incidents include enough prosaic detail to indicate that they record actual events. The attack on Guthlac by 'accursed spirits speaking Celtic' is one example. It stands out because it is unusual in two ways: it is the sole focus of the chapter in which it occurs, and it was set within a particularly specific time- 
frame, the brief reign of King Cœnred of Mercia (704 - 709) (Swanton 1993, p. 99). Finally, Felix himself took it for granted that late British polities were common in the seventh-and early eighth-century fenland. He explained, for example, that Guthlac was familiar with speakers of British Celtic 'because some time previously he had been in exile among them' (Swanton 1993, p. 99). Recent consideration of 'Guthlac A', a late eighth-century poem that describes disputes about property rights between the saint and his British 'demons', agrees that Guthlac established his hermitage within a minor late British kingdom (Clark 2011, pp. 85-87). Of interest in this connection is the name of Guthlac's father, the Mercian prince Penwealh, which includes the element -wealh, 'Briton' (Gray 1911, PASE).

Three documentary sources record Brittonic was still being spoken in the Cambridgeshire region around three centuries after Guthlac's death. The first is the most reliable. The regulations of a late tenth- or early eleventh-century guild of Cambridge thegns distinguished between members who spoke Old English and those who spoke Brittonic (Whitelock 1979, p. 658; Gray 1911). That is, there were still high status Brittonic-speakers living in or near Cambridge in about 1000. The second and third accounts were recorded in the twelfth-century Ramsey Chronicle. The first recounted an event said to have taken place between 1015 and 1035: a Danish lord of Therfield (Herts.) was so unpopular that his English retainers had to defend him while he slept. He woke up one night to overhear one guard asking another, "How long are we going to keep nightly watch for this foreign fellow, who deserves to be handed over to the Britons to murder?" (Gray 1911; Brady 2010, p. 681). (He sensibly left for London the next day.) The second account records ravages around St Ives (Hunts.) by wild and untamable British people, 'fera et indomita gens Britonum', between 1002 and 1090 (Gray 1911; Brady 2010, p. 681). Both accounts are problematic: they are secondary, their primary sources are not listed, they are uncorroborated, and they were written down at least a century after the events were supposed to have occurred. At very minimum, though, the fact that the Chronicle includes two stories about eleventh-century Britons in the region might give pause for thought. One story might be fanciful; but that there are two suggests that, whether or not the events described actually occurred, both writer and readers thought it was at least plausible that Brittonic was still commonly spoken in Cambridgeshire in the early eleventh-century.

\section{Place-names including elements drawn from British Celtic or Late Spoken Latin}

That conclusion of the continued occupation of the fenland throughout the early medieval period by Brittonic- and Late Spoken Latin-speaking communities is supported by three sets of fenland place-names: river- and place-names that preserve elements drawn from British Celtic, place-names including Late Spoken Latin elements, and Old English place-names that refer to individuals as wealh, 'Briton' (Figure 6).

River names were among the most common British Celtic place-names to survive into early medieval England, and the possibility of their persistence in fenland is not controversial. They are generally believed to include the Welland (Weolud, 921), Nene (Nyn, 948), Ouse (Usan, 880), and Granta (Gronte, c.745), as well as cam 'crooked' as applied to the winding course of the Old Croft River in Littleport (Camhale, 1251) (Ekwall 1928, pp. 1834, 299-300, 313-7; Reaney 1943, p. 226; Coates 2005, p. 318; Green 2012, p. 182; cf. Coates and Breeze 2000, p. 366 for scepticism concerning the first three). The name of the river Glen (Glein, $8^{\text {th }} / 9^{\text {th }} \mathrm{C}$ ) in Lincolnshire might also be added to that list as it may be derived from Brittonic *glanos 'pure, clear water' (Green 2012, pp. 173-82).

The reasons for the survival of this class of names are not known and inferences that might be drawn from them are fairly limited. Some may simply have been retained or adopted by Old English-speaking communities. More significant, however, are those river 
names included in the names of early territories. The Granta (now called the Cam) is an uncontroversially Brittonic name (Smith 1980, p. 36-7). It was the central feature of the territory of the grantasæte (cf. Grantchester) mentioned by Bede in 731, the -sæte suffix being distinctive of late British polities (ibid.). Holland ('haiw- 'lake, swamp') on the western silt fens is another late British territorial name: the area it represents is co-terminous with the wapentake of Elloe, includes the course of the river Glen, and may represent the territory of the spalde discussed above (Green 2012, pp. 173, 178, 182). Green has argued that the polity controlling Holland was predominantly Old English speaking by the seventh century, since the name of the spalde is Old English in origin, but that the survival of this and other Brittonic names within it may indicate that it had late British origins (2012, p. 183).

Brittonic place-name elements referring to more local features also survive in the fenland. Three are certainly British Celtic; a further five less certainly. Woodland (cēto-) survives at Chatteris (Cæateric, 974), Chettisham (Chetesham, c. 1170) and, perhaps, Chittering (Che(t)erring(e), 1423) (Reaney 1943, pp. xix, 247-8, 217, 185; Schram 1950, p. 430; though Coates proposes an alternative interpretation for Chatteris, 2005, p. 311). The pool, lïn, was the distinctive feature of (King's) Lynn (Schram 1950, p. 430; KEPN). Less certain are Tydd and Lutton in Holland, and Bretlond in Fleet (Coates \& Breeze 2000; Green 2012, p. 178; see Reaney 1943, pp. 283-4 for an OE interpretation of Tydd). Penhenorte (1251, now called Wood Fen) in Littleport is included here for completeness only; Reaney was unwilling to ascribe a meaning to it (1943, p. 228). The possibility that it incorporates British Celtic *penno- 'most important, high' can only be noted (Smith 1956, ii, pp. 61-2).

Two other place-names preserve elements of Late Spoken Latin. Funthams Farm (Funtune, 13thC) in Whittlesey is based on funta, 'a particularly Roman spring or well, perhaps one with special technology for drawing water' (Parsons 2011, p. 125; cf. Reaney 1943, p. 260; Smith 1956, i, p. 189). Since the site lies on the edge of wetland where drawing water would have been neither difficult nor unusual, the name may have referred to specialized technology for managing rather than accessing drinking water. 'Wykeham', a fifth- or sixth-century place-name derived from Latin vicus, 'a Romano-British administrative centre' lay just north of Spalding (Green 2012, p. 178).

In conclusion, traces of early medieval speakers of British Celtic, Late Spoken Latin and Old English can be found in place-names across the fen basin. The distribution of placenames in each language appears to be general across the fenland - there is no sign of any division of the region between them. That conclusion is supported by the distribution of Old English place-name elements describing Brittonic speakers.

\section{Old English -wealh in fenland names}

The Old English element -wealh, 'Briton', was recorded in some of the earliest documentary evidence (Whitelock 1979: p.403). Its inclusion in a number of place-names in different contexts across the fen basin extends the evidence for the persistence of communities speaking Brittonic in the early medieval period (Faull 1975; Cameron 1978-9, p. 33; Coates \& Breeze, 2000, p. 163). Such place-names fall into two groups: those apparently recording small estates belonging to individuals, and those that might refer to a political unit.

Three place-names record the individual holdings of Brittonic-speaking individuals. The first two combine wealh and worthig: Walewrth (13thC) in Ely and Waleuort (1251) at Horningsea (Reaney 1943, p. 218). Worthig, the 'inland' of an estate belonging a free landowner, was first documented in the late seventh-century laws of King Ine of Wessex (Faith 1997, p. 32). Ine's stipulation that worthigs should be 'fenced winter and summer' suggests that they were formally enclosed and, indeed, their curvilinear boundaries have 
been identified on upland Dartmoor (Whitelock 1979, p. 403; Faith 2004, p. 76; 2012). The fenland wealh worthigs were probably, then, the enclosed demesne farms of Brittonicspeaking gentry. The survival of the place-name at Ely and Horningsea confirms the evidence of the Cambridge guild regulations that such men could be found in major communities across the central and southern fenland, rather than in isolated, marginal locations. A third site has been recognised at Walecroft at Fleet in Lincolnshire, its 'croft' suffix suggesting a rather smaller holding (Penn 2005, p. 298).

The second group of potential wealh place-names in fenland is made up of three names now belonging to four contiguous parishes on the silt fens immediately east of Wisbech: Walsoken, Walpole (St Andrew and St Peter), and (West) Walton. All three names were first recorded between the late tenth and late eleventh centuries. Walsoken (Walsokne) was recorded in 974 when it was given to Ramsey Abbey by Ealdorman Æthelwin (Hart 1966, pp. 79, 241; PASE). Its second element is exceptionally rare: sōcn was an area of governance over a large estate or even a district (KEPN). Although doubts have been expressed about the authenticity of the charter, which was confirmed in about 1062, the form of the place-name has not been queried (eSawyer S798, S1030). Walpole (Walepol) was first recorded in 1016 in a charter of Bishop Elfwine; although the surviving charter is generally regarded as a reworking of an earlier original, the form of the place-name is regarded as genuine (eSawyer S1051; PASE; Hart 1966, p. 214; Fairweather 2005, p. 172). The second element in Walpole is pōl, 'pool' (Gelling \& Cole 2000, p. 28). Walton first appears as Waltuna in Domesday Book, its second element being -tūn, 'a small estate or community', a commonplace suffix (KEPN). There were large, permanent settlements in all three communities by the mid seventh century (Silvester 1985, p. 107; Silvester 1988, pp. 76, 84, 92; Hall \& Coles 1994, pp. 126-8).

Neither Smith nor Cameron interpreted the first element in any of these names as wealh; the former was explicit that all three names were based on weall, 'wall', while the latter did not include any of them in his gazetteer of names in wealh, 'Briton' (Smith 1956, ii, p. 244; Cameron 1978-9). Faull also interpreted Walsoken as 'weall', but did not discuss the other two $(1975$, p. 32). Silvester was ambivalent, noting that the possibility of 'the survival of a Celtic-speaking community, cannot entirely be dismissed' (1985, p. 108). Hall and Coles concluded that 'a more likely explanation of the name forms, in view of the Roman activity in the area, is from the Anglo-Saxon w(e)alh' (1994, p. 127). Gelling and Cole suggested that Walepol 'indicates the gen[itive] pl[ural] of Walh' 'Britons', but did not comment on Walsoken or West Walton (2000, p. 28, my additions). The sighting by Gelling and Cole of a wealh in Walpole thus remains unconfirmed.

Two questions have bedevilled these interpretations. The first is unanswerable: whether the phonetic similarity of the first element of the three place-names, modern 'Wal', reflects an origin in the same element or represents coincidental evolution to an apparently identical element from two or more different originals. The second question can be explored: If that first element does originated in the same word, is that word weall, 'wall', or wealh, 'Briton'? The 'wall' in question is the Sea (sometimes called 'Roman') Bank, a substantial, continuous earthwork around the shore of the Wash that protects inland settlements and fields from marine flooding (cf. Reaney 1943, p. 207; Figure 7). How likely is it that the Sea Bank is that 'wall'? The argument that there 'must have been' a pre-Conquest earthwork of some size because the place-name means 'wall' is circular and should be dismissed. Identification of the period of the Bank's construction may be more useful. 


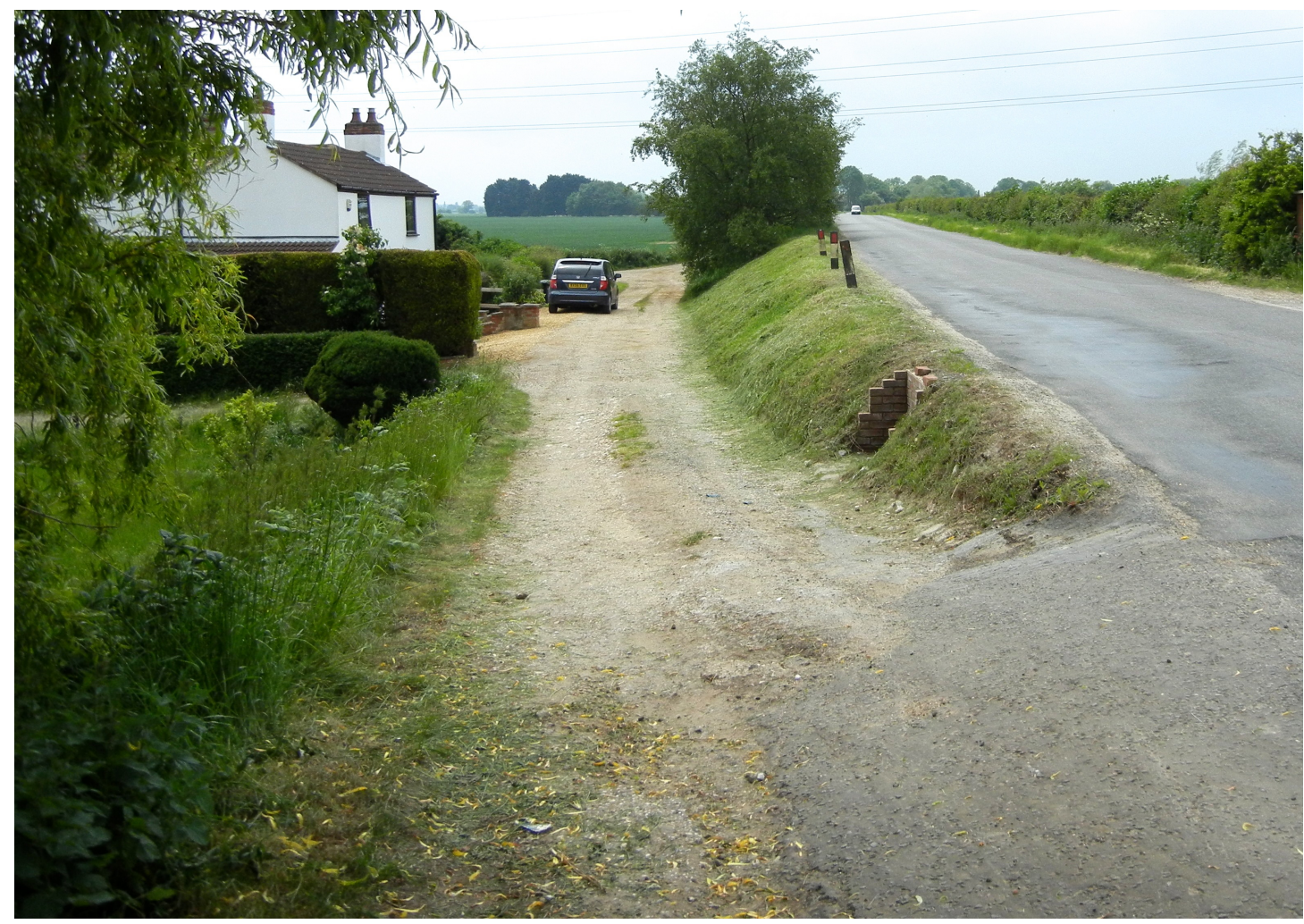

Figure 7. View west along the Sea Bank near Walpole St Peter, the Wash on the right and the reclaimed marsh on the left.

Although the Sea Bank was already described as 'old' by 1178 , it was probably constructed in the mid-eleventh century, connecting and significantly heightening discrete sets of low, tenth-century banks in each parish (Silvester 1988, p. 160; Penn 2005, p. 295). Those earlier earthworks have been upcast from small-scale systems of drains and small banks around separate sets of fields rather than deliberate construction of sea-facing dykes (Fowler 1950, p. 12). Until the end of the ninth century, there were no flood defences: before then most arable fields on the eastern silt fens were regularly flooded by the sea. The Sea Bank is, moreover, stratigraphically later than existing middle Anglo-Saxon fields at West Walton, around which it was diverted, and a middle Anglo-Saxon settlement at Tilney that it overlies (Silvester 1988, p. 70; Penn 2005, pp. 204-5, 295). The conclusion from archaeological and landscape evidence that the first element of the three place-names is unlikely to refer to the Sea Bank gains strength from the observation that the first documentary references to Walsoken (974) and Walpole (1016) predate the construction of the Sea Bank by at least half a century. A further complication is that, as Dr Owen explained, 'the normal term for a sea bank was dic' (dyke) rather than 'wall', so - if Walsoken, Walpole and Walton really were named from the Sea Bank - they should have been called Dic-sōcn, Dic-pōl and Dic-tūn (Silvester 1988, p. 160). Overall, it seems unlikely that these three settlements were named from the Sea Bank. On the other hand, the possibility that the three names share a common first element may be supported by evidence of their close administrative links.

\section{Late British polities in the early medieval eastern silt fens?}

In the mid-thirteenth century, Walton, Walsoken and Walpole were linked by administrative responsibilities as well as a shared place-name: with Terrington St Clement they comprised 
the 'leta integram de marisco' that had fiscal and judicial powers of governance of all aspects of common rights in the huge, 30,000-acre fen now divided into Marshland and the Smeeth (Douglas 1927, p. 195). The early origins of the Leet - an archaic, typically East Anglian, unit of medieval governance over an area smaller than a hundred - may be reflected in the precedence its decisions took over those of the manorial courts of the Bishop of Ely and the Abbey of Ramsey in those vills (e.g. Warner 1988, pp. 26-31; see Campbell 2005 for a dissenting view).

The differential distribution of rights of common period in Marshland may reveal something of the evolution of the early polity preserved in the Leet. By far the largest proportion of common rights were concentrated in three of its four vills: Walton, Walpole and Walsoken. Terrington St Clement had a much smaller share of rights of intercommon, both in absolute and proportionate terms, than the three parishes to its west while its later daughter settlement, Terrington St John, had virtually none. The Tilneys (including Islington), the Wiggenhalls and Clenchwarton, which all lay outside the leet, had almost no common rights in Marshland (Silvester 1988, pp. 34, 157, 159). The vills that dominated intercommoning in Marshland - Walpole, Walsoken, West Walton and Terrington St Clement - are also those in which there is evidence of large-scale, permanent settlement by about 650 (Silvester 1985, p. 107; Silvester 1988, pp. 76, 84, 92; Hall \& Coles 1994, pp. 126-8). By contrast, those vills that were almost completely excluded from intercommoning in Marshland - Terrington St John, Clenchwarton, Tilney All Saints and the Wiggenhalls - are those in which there is little or no evidence of occupation until the late Saxon period at the earliest (Silvester 1988, pp. 60,157, 159). That is, the number of grazing rights allocated to each vill appears to record the chronology of territorial development across the eastern siltland as a whole. The dominance of Walsoken, Walpole and Walton suggests that most common rights in Marshland had already been allocated by the time that the settlement at Terrington St Clement had emerged. Since a substantial settlement covering over 7 hectares was flourishing there by the mid-seventh century, it seems possible that the origins of the Leet might be found in a polity of the sixth or even fifth century (Silvester 1988, p. 37). If that were the case, it might explain why, when permanent occupation once more became possible across the eastern silts in the mid-seventh century, seven settlements were laid out in apparently planned, carefully spaced intervals of 1.5 and $2 \mathrm{~km}$ between the Norfolk fenedge and Wisbech - they already lay within a structured political unit (Silvester 1988, p. 158).

The -sōcn element recorded at Walsoken in 974 assumes a particular significance in this context. Could the mid-thirteenth century Leet be the successor to the -sōcn? There is a significant overlap in the definition of the two terms: $-s \bar{c} c n$ indicates governance of a political unit from a large estate to a district, and leet an area larger than a vill and smaller than a hundred. Both the repetition of the same first element in the place-names of Walsoken, Walpole and Waltun, their geographic contiguity, and their shared dominance of the Leet further suggest a common origin. While the interpretation of the first element of their place- name from wealh, 'Briton', remains controversial, there has nonetheless been a slight shift in opinion in its favour (Silvester 1985, p. 108; Hall \& Coles 1994, p. 127; Gelling \& Cole 2000, p. 28). It is possible that the silt fens to the east of Wisbech lay within an ancient $-s o \bar{c} n$, aspects of whose governance persisted in the 'leta integram de marisco'. If the shared first element in the three place-names is indeed wealh, perhaps that community may have been Brittonic-speaking.

\section{Conclusion}


Archaeological evidence indicates little post-Roman abandonment of the fenland; the region continued to be inhabited and exploited. Patterns of intercommoning, the Tribal Hidage, and stray pieces of information recorded by Bede and Felix, demonstrate the presence of territorial groups across the whole basin by the mid-seventh century in a complex, almost certainly dynamic, hierarchy of subordinate and dominant polities, principalities and kingdoms, some with some Brittonic territorial names and others with names based on Old English elements. Most of the people who gave these place-names were like to have been descended from the Romano-British and prehistoric inhabitants of Britain. Different cultural traditions cannot be identified in their material culture, and many may have been bilingual. Such commonalities together with continuity across the region in structures governing rights of common pasture suggests that it is as likely that some sub-Roman polities evolved into sub-kingdoms as it is that other polities were created anew. There is nothing so out of the ordinary in such political changes that they might be ascribed to the influence of incomers. The influence of migration on the evolution of early medieval fenland culture remains enigmatic.

\section{ACKNOWLEDGEMENTS}

I am grateful to the two anonymous referees whose comments on an earlier draft have been particularly helpful. Dr Keith Briggs kindly corresponded with me about interpretations of place-names at Walsoken, Walpole and West Walton, and shared copies of pre-publication drafts of two of his papers. Dr Caitlin Green was also good enough to comment on an earlier draft. The figures have been drawn by Mrs Sarah Wroot. Mistakes and misapprehensions, as ever, remain my own.

\section{BIBLIOGRAPHY}

\section{Primary sources}

Bede. Ecclesiastical History of the English People. L. Sherley-Price, ed., 1990. London: Penguin.

Ely Coucher Book 1251 (ECB), late $14^{\text {th }}$-century ms., Cambridge University Library EDR G3/27.

Ely Coucher Book 1251, 13th-century ms., British Library Cott.Claud.C.xi.

Felix. The Life of St Guthlac. In: M. Swanton, ed., 1993. Anglo-Saxon Prose. London: Penguin, 88-113.

Gildas. The Ruin of Britain. M. Winterbottom, ed., 1978. Chichester: Phillimore.

Liber Eliensis (LE). A History of Ely from the Seventh Century to the Twelfth, compiled by a Monk of Ely in the Twelfth Century. J. Fairweather, ed., 2005. Woodbridge: Boydell.

\section{Secondary sources}

Arnold, C. J., 1988. An Archaeology of the Early Anglo-Saxon Kingdoms. London: Routledge.

Brady, L., 2010. 'Echoes of Britons on a fenland frontier in the Old English Andreas.' Review of English Studies NS 61, 252, 669-689.

Brather, S., 2005. 'Acculturation and ethnogenesis along the frontier: Rome and the ancient Germans in an archaeological perspective'. In: F. Curta, ed., Borders, Barriers and Ethnogenesis. Turnhout: Brepols, 139-172. 
Briggs, K., (forthcoming). 'Early English regional-names with the suffix -ia. With special emphasis on the name Ely.'

Cameron, K., 1978-9. 'The meaning and significance of Old English walh in English placenames.' Journal of the English Place-Name Society 12, 1-46.

Campbell, J., 2005. 'Hundreds and leets: A survey with suggestions'. In: C. Harper-Bill, ed., Medieval East Anglia. Woodbridge: Boydell, 153-167.

Capelli, C., et al., 2003. 'A Y chromosome census of the British Isles', Current Biology 13, 979984.

Carver, M., 1994. 'Environment and commodity in Anglo-Saxon England'. In: J. Rackham, ed., Environment and Economy in Anglo-Saxon England. York: Council for British Archaeology, 1-6.

Clark, S., 2011. 'A more permanent homeland: Land tenure in Guthlac A.' Anglo-Saxon England 40, 75-102.

Coates, R., 2005. 'Four pre-English river names in and around fenland: Chater, Granta, Nene and Welland'. Transactions of the Philological Society 103 (3), 303-322.

Coates, R. and Breeze, A., eds., 2000. Celtic Voices English Places. Stamford: Shaun Tyas.

Crowson, A., Lane, T., Penn, K. and Trimble, D., 2005. Anglo-Saxon Settlement on the Siltland of Eastern England. Heckington: Lincolnshire Society for Archaeology and History.

Darby, H. C., 1934. 'The fenland frontier in eastern England'. Antiquity 8 (30), 185-201.

Darby, H. C., 1940. Medieval Fenland. Cambridge: Cambridge University Press.

Davies, W. and Vierck, H., 1974. 'The contexts of the Tribal Hidage: Social aggregates and settlement patterns'. Frühmittelalterliche Studien 8, 223-93.

Douglas, C., 1927. The Social Structure of Medieval East Anglia. Oxford: Clarendon Press.

Ekwall, E., 1928. English River-Names. Oxford: Clarendon.

Faith, R., 1997. The English Peasantry and the Growth of Lordship. Leicester: Leicester University Press.

Faith, R., 2004. 'Cola's tūn: Rural social structure in late Anglo-Saxon Devon'. In: R. Evans, ed., Lordship and Learning. Studies in memory of Trevor Aston. Woodbridge: Boydell, 63-78.

Faith, R., 2012. 'Some Devon farms before the Norman conquest'. In: S. Turner and B. Silvester, eds., Life in Medieval Landscapes. People and Places in the Middle Ages. Oxford: Windgather, 73-88.

Faull, M., 1975. 'The semantic development of Old English wealh'. Leeds Studies in English n.s. $8,20-44$.

Fox, C., 1923. Archaeology of the Cambridge Region. Cambridge: Cambridge University Press.

Fowler, G., 1950. 'A Romano-British village near Littleport, Cambs.' Proceedings of the Cambridge Antiquarian Society 43, 7-20.

Geary, P., 2002. The Myth of Nations. The Medieval Origins of Europe. Princeton, Princeton University Press.

Gelling, M. and Cole, A., 2000. The Landscape of Place-Names. Stamford, Shaun Tyas.

Gillett, A., 2006. 'Ethnogenesis: A contested model of early medieval Europe'. History Compass 4, $241-260$. 
Goffart, W., 2006. 'The barbarians in late antiquity and how they were accommodated in the west'. In: T. Noble, ed., From Roman Provinces to Medieval Kingdoms. London: Routledge, 235 - 61.

Gray, A., 1911. 'On the late survival of a Celtic population in East Anglia'. Proceedings of the Cambridge Antiquarian Society 15, 42-52.

Green, T., 2012. Britons and Anglo-Saxons. Lincolnshire AD 400-650. Lincoln, History of Lincolnshire Committee.

Hall, D., 1987. The Fenland Project, Number 2: Fenland Landscapes and Settlement between Peterborough and March. East Anglian Archaeology 35.

Hall, D., 1996. The Fenland Project, Number 10: Cambridgeshire Survey, The Isle of Ely and Wisbech. East Anglian Archaeology 79.

Hall, D. and Coles, J., 1994. Fenland Survey. An Essay in Landscape and Persistence. Swindon: English Heritage.

Hamerow, H., 1997. 'Migration theory and the Anglo-Saxon 'identity crisis". In: J. Chapman and H. Hamerow, eds., Migrations and Invasions in Archaeological Explanation.

Oxford: Noyes Press, 33-44.

Hart, C. R., 1966. Early Charters of Eastern England. Leicester: Leicester University Press.

Hart, C. R., 1971. 'The Tribal Hidage'. Transactions of the Royal Historical Society, $5^{\text {th }}$ Series, 21, 133-157.

Hayes, P. and Lane, T., 1992. The Fenland Project Number 5: Lincolnshire survey, the southwest fens. East Anglian Archaeology 55.

Henig, M., 2004. 'Roman Britain after 410'. British Archaeology 68, 8-11.

Hills, C., 2011. 'Overview: Anglo-Saxon identity'. In: H. Hamerow, D. Hinton and S. Crawford, eds., Oxford Handbook of Anglo-Saxon Archaeology. Oxford: Oxford University Press, 3-12.

Hoskins, W. G., 1955. The Making of the English Landscape (1988 ed.). London: Guild.

Hughes, S., et al., 2014. 'Anglo-Saxon origins investigated by isotopic analysis of burials from Berinsfield, Oxfordshire, UK'. Journal of Archaeological Science 42, 81 - 92.

Laing, L., 2007. 'Romano-British metalworking and the Anglo-Saxons'. In N. Higham, ed. Britons in Anglo-Saxon England. Woodbridge: Boydell Press, 42-56.

Leslie, S., et al., 2015. 'The fine-scale genetic structure of the British population'. Nature 51: 309-314.

Lethbridge, T., 1931. 'Recent excavations in Anglo-Saxon cemeteries in Cambridgeshire and Suffolk'. Cambridge Antiquarian Society, Quarto Publications, New Series III.

Lucy, S. and Reynolds. A., 2002. 'Burial in early medieval England and Wales: Past, present and future'. In: S. Lucy and A. Reynolds, eds., Burial in Early Medieval England and Wales. London: Society for Medieval Archaeology, 1-23.

Maitland, F., 1897. Domesday Book and Beyond. Cambridge: Cambridge University Press.

Millett, M., 1990. The Romanization of Britain. Cambridge: Cambridge University Press.

Nash Briggs, D., 2011. 'The language of inscriptions on Icenian coinage'. In: J. A. Davies, ed., The Iron Age in Northern East Anglia: New Work in the Land of the Iceni. Oxford: BAR British Series No. 549, 83-102. 
Neilson, N., ed., 1920. A Terrier of Lincolnshire. London: British Academy.

Newman, J., 2002. 'Sutton Hoo before Rædwald'. Current Archaeology 180, 498-505.

Parsons, D., 2011. 'Sabrina in the thorns: Place-names as evidence for British and Latin in Roman Britain'. Transactions of the Philological Society 109, 113-137.

Pattison, J. E., 2008. 'Is it necessary to assume an apartheid-like social structure in early Anglo-Saxon England?' Proceedings of the Royal Society B, 275, 2423-2429.

Penn, K., 2005. 'Discussion and conclusions'. In: A. Crowson, T. Lane, K. Penn and D. Trimble, Anglo-Saxon Settlement in the Siltland of Eastern England. Heckington: Lincolnshire Society for Archaeology and History, 289-300.

Phillips, C. W., ed., 1970. The Fenland in Roman Times. London: Royal Geographical Society.

Pohl, W., 1997. 'Ethnic names and identities in the British Isles: A comparative perspective'. In: J. Hines, ed., The Anglo-Saxons from the Migration Period to the Eighth Century. An Ethnographic Perspective. Woodbridge: Boydell, 7-40.

Reaney, P. H., 1943. Place-Names of Cambridgeshire and the Isle of Ely. Cambridge: Cambridge University Press.

Rippon, S., 2013. 'Human impact on the coastal wetlands of Britain in the medieval period'. In: E. Thoen, et al., eds., Landscapes or Seascapes? The history of the coastal environment in the North Sea area reconsidered. Turnhout: Brepols, 333-352.

Roberts, B. K. and Wrathmell, S., 2002. Region and Place. Swindon: English Heritage.

Roffe, D., 1993. 'On middan Gyrwan fenne: intercommoning around the island of Crowland'. Fenland Research 8, 80-86.

Roffe, D., 2005. 'The historical content'. In: A. Crowson, T. Lane, K. Penn and D. Trimble, Anglo-Saxon Settlement in the Siltland of Eastern England. Heckington: Lincolnshire Society for Archaeology and History, 264-88.

Schram, O., 1950. 'Fenland place-names'. In: C. Fox and B. Dickins, eds., The Early Cultures of North-West Europe. Cambridge: Cambridge University Press, 427-441.

Schrijver, P., 2014. Language Contact and the Origins of the Germanic Languages. London: Routledge.

Silvester, R., 1985. 'West Walton: The development of a siltland parish'. Norfolk Archaeology 19 (2), 101-117.

Silvester, R., 1988. The Fenland Project, Number 3: Norfolk Survey, Marshland and the Nar Valley. East Anglian Archaeology 45.

Skeat, W., 1901. The Place-Names of Cambridgeshire. Cambridge: Cambridge Antiquarian Society, Octavo No. XXVI.

Smith, A. H., ed., 1956. English Place-Name Elements, 2 vols. Cambridge: Cambridge University Press.

Smith, C., 1980. 'The survival of Romano-British toponymy'. Nomina 4, 27-40.

Stenton, F. M., 1971. Anglo-Saxon England. Oxford: Oxford University Press.

Taylor, C. C., 1973. The Cambridgeshire Landscape. London: Hodder and Stoughton.

Tristram, H., 2007. 'Why don't the English speak Welsh?' In: N. Higham, ed., Britons in AngloSaxon England. Woodbridge: Boydell, 192-214.

Tyler, D., 2007. 'Early Mercia and the Britons'. In: N. Higham, ed., Britons in Anglo-Saxon 
England. Woodbridge: Boydell, 91-101.

Wareham, A. and Wright, A., eds., 2002. Victoria County History of Cambridgeshire and the Isle of Ely ( $\mathrm{VCH})$, Vol. 10. London: Institute for Historical Research.

Warner, P., 1988. 'Pre-Conquest territorial and administrative organisation in East Suffolk'. In: D. Hooke, ed., Anglo-Saxon Settlements. Oxford: Blackwell, 9-34.

Weale, M. E., et al., 2002. 'Y chromosome evidence for Anglo-Saxon mass migration'. Molecular Biological Evolution 19, 1008-1021.

Webster, C., 1987. 'Ernest Greenfield's excavations at Exning Roman villa'. Proceedings of the Cambridge Antiquarian Society 76, 41-66.

Whitelock, D., 1979. English Historical Documents, c.500-1042. London: Routledge.

Wilson, D. M., 1976. 'Introduction'. In: D. M. Wilson, ed., The Archaeology of Anglo-Saxon England. Cambridge: Cambridge University Press, 1-22.

Williamson, T., 2010. 'The Environmental Contexts of Anglo-Saxon Settlement'. In: N. Higham, and M. Ryan, eds., Landscape Archaeology of Anglo-Saxon England. Woodbridge: Boydell, 133-156.

\section{Online resources}

Cambridgeshire Historic Environment Record (CHER), http://www.heritagegateway.org.uk/gateway, accessed July 2014.

Electronic Sawyer, Online catalogue of Anglo-Saxon charters. www.esawyer.org.uk, accessed July 2014.

English Place-Name Society, Key to English Place-Names (KEPN) www.kepn.nottingham.ac.uk, accessed July 2014.

Ouse Washes Landscape Partnership (OWLP) 2013. Landscape Conservation Action Plan. Section 1. Understanding the Landscape Partnership Scheme Area. https://ousewashes/ps.files.wordpress.com/2013/02/05-section-1-understanding-thelandscape-partnership-scheme-area.pdf, accessed July 2014.

Prosopography of Anglo-Saxon England (PASE), King's College London 2010. www.pase.ac.uk, accessed July 2014. 